\title{
The Relationship between Pre-Service Primary School Teachers' Mathematics Teaching Anxiety and Their Beliefs about Teaching and Learning Mathematics*
}

\author{
Kübra BAŞPINAR ${ }^{* *}$ \\ Murat PEKER ${ }^{* * *}$
}

Received: 09 November 2015

Accepted: 08 December 2015

\begin{abstract}
The purpose of this study was to investigate the relationship between pre-service primary school teachers' mathematics teaching anxiety and their beliefs about teaching and learning mathematics. There were a total of 250 pre-service primary school teachers involved in this study. Of the total, 202 were female and 48 were male pre-service primary school teachers. In the collection of the data, the researchers employed two types of instruments: the Mathematics Teaching Anxiety Scale (MATAS) and the Mathematics Related Beliefs Scale (MRBS). MATAS, which was developed by Peker (2006), was used to identify the pre-service teachers' anxiety about teaching mathematics. MATAS is a five-point Liker-type scale with 23 positive and negative items. MRBS, which was developed by Kayan, Haser and Işıksal Bostan (2013), was used to identify their beliefs about teaching and learning mathematics. MRBS is a five-point Liker-type scale with 26 items. The correlation analysis statistics was performed to identify the relationship between pre-service primary school teachers' mathematics teaching anxiety and their beliefs about teaching and learning mathematics. The study revealed that there were a significant, negative relations between pre-service primary school teachers' mathematics teaching anxiety and their beliefs about teaching and learning mathematics ( $\mathrm{r}=-.428$; $\mathrm{p}<0.01)$.
\end{abstract}

Keywords: mathematics; teaching anxiety; beliefs; pre-service teacher

\section{Introduction}

Mathematics is one of the most important components of the education (Umay, 2003), and it can be described as the common name of the sciences which is based on numbers and measures such as arithmetic, geometry and algebra (Karakurumer, 2003). Karakurumer (2003) stated that mathematics is a common thought system and a common language which has been prevalent effective and continuous since prehistorical times, and it has been of importance for a wide range of fields such as science, technic, economy, health and administration. Mathematics is considered difficult all over the world due to its extensive use of in our Daily life, and the instruction of mathematics is difficult to teach (Yüksel-Şahin, 2004). It is a course which students like, scare or hate in the beginning of their education (Yenilmez \& Can, 2006). Delice, Ertekin, Aydın and Dilmaç (2009) also argued that it is a field toward which students, pre-service teachers

\footnotetext{
* This study is a part of first author's master thesis. Also a part of this study was presented as an oral presentation at the International Conference on Social Sciences and Education Research on 29-31 October 2015.

** Corresponding Author: Teacher, Akören Middle School, Afyonkarahisar, Turkey, kubra_yavasca@hotmail.com

As* Assoc. Prof., Afyon Kocatepe University, Afyonkarahisar, Turkey, peker@aku.edu.tr
}

\section{Citation Information}

Başpınar, K. \& Peker, M. (2016). The relationship between pre-service primary school teachers' mathematics teaching anxiety and their beliefs about teaching and learning mathematics. Kuramsal Eğitimbilim Dergisi [Journal of Theoretical Educational Science], 9(1), 1-14. 
and even teachers have negative attitudes. The students think that mathematics is a difficult subject and they will fail, and these views create anxiety among (Yenilmez \& Özbey, 2006). As a solution, Köroğlu and Yeşildere (2004) suggested the understanding the nature of mathematics as the way to achieve mathematics.

According to Peker (2006), teachers might control this anxiety if they become aware of the mathematics anxiety of their students. Considering the fact that teachers are the first actors who play an active role in a learning environment and make the learning process easier or more difficult, it is easier to understand the significance of teachers in the instruction of mathematics (Turanl1, Karakaş Türker, \& Keçeli, 2008). The learning anxiety of students has positive or negative effects on learning. Furthermore, the teaching anxiety of teachers or pre-service teachers has negative or positive effects on their instruction or the learning of students. Gardner and Leak (1994) define the teaching anxiety as the anxiety which is experienced in the instruction process including the preparation and application of in-class activities. Accordingly, mathematics teaching anxiety is defined as the anxiety which teachers experienced in the teaching of mathematical concept, theorem, formula and problem-solving (Peker, 2006). In the literature, there can be found many studies regarding the mathematics anxiety of pre-service teachers (Ertekin, 2010; Ertekin, Dilmaç, Yazıc1, \& Peker, 2010; Peker, 2008; 2009a; 2009b; 2009c; 2015; Peker \& Ertekin, 2011; Ural, 2015; Yaz1c1, Peker, Ertekin, \& Dilmaç, 2011). In these studies, the mathematics teaching anxiety was examined with different variables, and the different results were gained. To give some examples, a negative moderate relationship was found between the self-efficacy perceptions of pre-service teachers and their mathematics teaching anxieties (Ural, 2015). A negative moderate relationship was found between the self-efficacy perceptions of pre-service teachers toward mathematics teaching and their mathematics teaching anxieties (Peker, 2015). Besides, a moderate positive relationship was found between the mathematics anxiety of pre-service teachers and their mathematics teaching anxieties (Peker \& Ertekin, 2011). In another study, low positive relationship was found between the mathematics teaching anxiety of pre-service teachers and mathematical values, and the constructivist values are the predictor of mathematics teaching anxieties (Yazıcı, Peker, Ertekin, \& Dilmaç, 2011). Furthermore, a low relationship was found between the mathematical beliefs of pre-service teachers and their mathematics teaching anxieties (Ertekin, 2010), and a low negative relationship was found between the mathematics teaching anxiety of pre-service teachers and their epistemological beliefs (Ertekin, Dilmaç, Yazıc1, \& Peker, 2010). As the concretization need increases in the group which pre-service teachers will teach mathematics, their teaching anxiety increases (Peker, 2008).

Another affective factor which has a significant effect on teaching and learning is the beliefs. The beliefs on mathematics has essential role in the teaching of mathematical knowledge (Sezgin Memnun, 2015). Mathematical belief is defined as the personal judgements which they gained through the experiences regarding mathematics, and it includes the beliefs regarding the nature of mathematics and the significance of 
mathematics teaching and learning (Raymond \& College, 1997). Schoenfeld (1992) and Thompson (1992) stated that a major part of the mathematical beliefs which includes the personal views regarding the nature, significance and teaching of mathematics is formed and developed throughout the school life (as cited in Sezgin Memnun, 2015). In the study of Howard, Perry and Lindsay (1997), teachers have beliefs regarding the nature, learning and teaching of mathematics, and these beliefs which are described as "traditional" and "constructivist" have an effect on the teaching of mathematics by teachers. Similarly, the recent studies suggest that the beliefs of teachers and pre-service teachers have an effect on their behaviors and attitudes in the teaching process (Baydar \& Bulut, 2002; Hacıömeroğlu, 2011; 2013; Haser \& Doğan, 2012; Kayan \& Çakıroğlu, 2008; Paksu, 2008; Toluk-Uçar \& Demirsoy, 2010). It is also possible to a range of studies which examine the relationship between mathematics teaching and the beliefs on mathematics (Hacı̈̈meroğlu, 2013; Uusimaki \& Nason, 2004; Walsh, 2008 and so on). Walsh (2008) found that there is not a statistically significant difference between mathematics anxiety and the beliefs on mathematics in his study on nursing students. Uusimaki and Nason (2004) concluded that the negative beliefs and mathematics anxieties of classroom primary school teachers toward mathematics have its sources from the instruction in primary schools. Haciömeroğlu (2013) found a low negative relationship between the mathematics anxiety of primary school teachers and their mathematical beliefs. However, there is not any study which examines the relationship between the mathematics anxiety of primary school teachers toward mathematics teaching and their beliefs on mathematics learning and teaching. Therefore, this study was expected to contribute to the field of mathematics in order to fill this gap.

Considering the all these factors, the current study aims to examine the relationship between the mathematics anxiety of primary school teachers toward mathematics teaching and their beliefs on mathematics learning and teaching.

\section{Method}

This study is an associational research which is one of the descriptive research types and describes the relationships between variables. In the study, the anxiety levels of the participants toward mathematics teaching and their beliefs on mathematics learning and teaching were examined through "Mathematics Teaching Anxiety Scale" and "Mathematics Related Beliefs Scale". Then, the relationship between the anxiety toward mathematics teaching and the beliefs on mathematics teaching and learning were scrutinized.

\section{Participants}

A purposive sampling which is not a random sampling was used in the study (Büyüköztürk, Kılıç Çakmak, Akgün, Karadeniz, \& Demirel, 2012). The participants were comprised of 250 3rd and 4th grade pre-service teachers who study at a university in the Aegean region of Turkey. All the participants passed the basic mathematics and mathematics instruction courses, and the participants at 4th grade completed their practicum and became ready for the teaching career. The number of male participants 
was 48, and the number of the female participants was 202. The participants participated in the study voluntarily.

\section{Instruments}

In the study, two instruments were used to collect the data. The first of these was "Mathematics Teaching Anxiety Scale", and the other one was "Mathematics Related Beliefs Scale”.

Mathematics teaching anxiety scale. The Mathematics Teaching Anxiety Scale which was developed by Peker (2006) includes 23 items in four factors, and makes use of 5-point Likert type. These sub factors are as follows: 10 items- the anxiety originated from content knowledge, 6 items- the anxiety originated from self-efficacy, 4 items- the anxiety originated from the attitude toward mathematics teaching and 3 items- the anxiety originated from pedagogical content knowledge. The reliability and validity of the scale was first carried out by Peker (2006), and the following factor loadings were found for the sub factors: between 0.53 and 0.86 for the anxiety originated from content knowledge, between 0.57 and 0.76 for the anxiety originated from self-confidence, between 0.61 and 0.71 for the anxiety originated from the attitude toward mathematics teaching and between 0.68 and 0.78 for the anxiety originated from pedagogical content knowledge. The Cronbach's alpha coefficient was computed for the whole scale, and it was found as 0.90 . The Cronbach's alpha coefficient was also computed for the sub factors, and the following values were found: 0.83 for the anxiety originated from content knowledge, 0.71 for the anxiety originated from self-confidence, 0.61 for the anxiety originated from the attitude toward mathematics teaching and 0.91 for the anxiety originated from pedagogical content knowledge. In the current study, the Cronbach's alpha coefficient was found to be 0.93 , and it was also computed for the sub factors: 0.92 for the anxiety originated from content knowledge, 0.86 for the anxiety originated from self-confidence, 0.88 for the anxiety originated from the attitude toward mathematics teaching and 0.87 for the anxiety originated from pedagogical content knowledge.

Mathematics related beliefs scale. The Mathematics Related Beliefs Scale which was developed by Kayan, Haser and Iş1ksal Bostan (2013) consists of 26 items having 2 sub factors, and it makes use of 5-point Likert type. These sub factors are as follows: 20 items- constructivist beliefs and 6 items- traditional beliefs. The reliability and validity of the scale was first carried out by Kayan, Haser and Işıksal Bostan (2013), and the items which had factor loadings over 0.40 were included in the scale. Furthermore, the relationship among the factors was computed as 0.055, and the factor analysis seemed to be adequate as the value was lower than the highest value (0.3). The Cronbach's alpha coefficient was computed for the whole scale, and it was found as 0.83. The Cronbach's alpha coefficient was also computed for the sub factors, and the following values were found: 0.84 for the sub factor of constructivist beliefs and 0.73 for the sub factor of traditional beliefs. In the current study, the Cronbach's alpha 
coefficient was found to be 0.85 , and it was also computed for the sub factors: 0.86 for the sub factor of constructivist beliefs and 0.65 for the sub factor of traditional beliefs.

\section{Data Analysis}

Pearson's product-moment correlation coefficient was analyzed to examine the relationship between the mathematics anxiety of primary school teachers toward mathematics teaching and their beliefs on mathematics learning and teaching.

The significance level was accepted as 0.05 and 0.01 based on the results. Besides, Pearson's product-moment correlation coefficient was evaluated as follows: low level between 0.00 and 0.30 , moderate level between 0.30 and 0.70 , high level between 0.70 and 1.00 (Büyüköztürk, 2012).

\section{Results}

The results of Pearson's product-moment correlation coefficient analysis which was carried out to examine the relationship between the mathematics anxiety of primary school teachers toward mathematics teaching and their beliefs on mathematics learning and teaching was given in Table 1.

\section{Table 1}

The relationship between the mathematics teaching anxiety of primary school teachers and their beliefs on mathematics learning and teaching $(N=250)$

\begin{tabular}{ccc} 
& & Beliefs on Mathematics Learning and Teaching \\
\hline & $r$ & $-.428^{* *}$ \\
Anxiety toward Mathematics Teaching & $p$ & .000 \\
& $r^{2}$ & 0.18 \\
\hline$* * p<0.01$ & &
\end{tabular}

As can be seen in Table 1, the Pearson's product-moment correlation coefficient analysis which was carried out to examine the relationship between the mathematics anxiety of primary school teachers toward mathematics teaching and their beliefs on mathematics learning and teaching was found to be $(r=-.428 ; p<0.01)$. In other words, a negative moderate significant relationship was found between the mathematics anxiety of primary school teachers toward mathematics teaching and their beliefs on mathematics learning and teaching. Therefore, it can be said that the belief levels on mathematics teaching and learning decrease as the anxiety levels toward mathematics teaching increase. Similarly, it can also be said that the belief levels on mathematics teaching and learning increase as the anxiety levels toward mathematics teaching decrease. Considering the determination coefficient $\left(r^{2}=0.18\right), 18 \%$ of the total variation of the items regarding the mathematics teaching anxiety can be interpreted to be related to the belief levels on mathematics teaching and learning. 
Furthermore, the relationship among the sub factors of the mathematics teaching anxiety scale and the sub factors of mathematics related beliefs scale was examined. The Pearson's product-moment correlation coefficient analysis which was carried out to examine the relationships among the sub factors was presented in Table 2.

Table 2

The relationship among the sub factors of the mathematics teaching anxiety scale and the sub factors of mathematics related beliefs scale $(N=250)$

\begin{tabular}{|c|c|c|c|c|}
\hline & & & \multicolumn{2}{|c|}{ Beliefs on Mathematics Learning and Teaching } \\
\hline \multicolumn{3}{|c|}{ Sub Factors } & Constructivist Belief & Traditional Belief \\
\hline \multirow{12}{*}{ 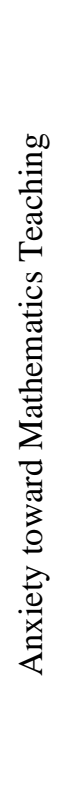 } & \multirow{3}{*}{ Content Knowledge } & $r$ & $-.427 * *$ & -.040 \\
\hline & & $p$ & .000 & .532. \\
\hline & & $r^{2}$ & 0.18 & 0.002 \\
\hline & \multirow{3}{*}{ Self-confidence } & $r$ & $-.228 * *$ & -.075 \\
\hline & & $p$ & .000 & .239 \\
\hline & & $r^{2}$ & 0.05 & 0.006 \\
\hline & \multirow{3}{*}{$\begin{array}{c}\text { Attitude toward Mathematics } \\
\text { Teaching }\end{array}$} & $r$ & $-.453 * *$ & -.067 \\
\hline & & $p$ & .000 & .288 \\
\hline & & $r^{2}$ & 0.21 & 0.005 \\
\hline & \multirow{3}{*}{$\begin{array}{l}\text { Pedagogical Content } \\
\text { Knowledge }\end{array}$} & $r$ & $-.476^{* *}$ & -.110 \\
\hline & & $p$ & .000 & 0.84 \\
\hline & & $r^{2}$ & 0.23 & 0.02 \\
\hline
\end{tabular}

As can be seen in Table 2, the Pearson's product-moment correlation coefficient analysis which was carried out to examine the relationship between the sub factor of the anxiety originated from content knowledge from the mathematics teaching anxiety scale and the sub factor of constructivist belief from the mathematics related beliefs scale produced the value of $(\mathrm{r}=-.427 ; \mathrm{p}<0.01)$. Accordingly, a negative moderate significant relationship was found between the anxiety levels originated from content knowledge and constructivist beliefs. Therefore, it can be said that the anxiety levels originated from content knowledge increase as the constructivist belief levels decrease. Similarly, it can be said that the anxiety levels originated from content knowledge decrease as the constructivist belief levels increase. Considering the determination coefficient $\left(r^{2}=0.18\right), 18 \%$ of the total variation of the items regarding the anxiety originated from content knowledge can be interpreted to be related to the constructivist belief levels. 
The Pearson's product-moment correlation coefficient analysis which was carried out to examine the relationship between the sub factor of the anxiety originated from content knowledge from the mathematics teaching anxiety scale and the sub factor of traditional belief from the mathematics related beliefs scale produced the value of ( $r=-.040 ; p>0.05)$. Accordingly, a significant relationship could not be found between the anxiety levels originated from content knowledge and traditional beliefs.

The Pearson's product-moment correlation coefficient analysis which was carried out to examine the relationship between the sub factor of the anxiety originated from self-confidence from the mathematics teaching anxiety scale and the sub factor of constructivist belief from the mathematics related beliefs produced the value of $(\mathrm{r}=-.228 ; \mathrm{p}<0.01)$. Accordingly, a negative low significant relationship was found between the anxiety levels originated from self-confidence and constructivist beliefs. Therefore, it can be said that the anxiety levels originated from self-confidence increase as the constructivist belief levels decrease. Similarly, it can also be said that the constructivist beliefs increase as the anxiety levels originated from self-confidence decrease. Considering the determination coefficient $\left(r^{2}=0.05\right)$, $5 \%$ of the total variation of the items regarding the anxiety originated from self-confidence can be interpreted to be related to the constructivist belief levels.

The Pearson's product-moment correlation coefficient analysis which was carried out to examine the relationship between the sub factor of the anxiety originated from self-confidence from the mathematics teaching anxiety scale and the sub factor of traditional belief from the mathematics related beliefs produced the value of $(r=-.075$; $\mathrm{p}>0.05$ ). Accordingly, a significant relationship could not be found between the anxiety levels originated from self-confidence and traditional beliefs.

The Pearson's product-moment correlation coefficient analysis which was carried out to examine the relationship between the sub factor of the anxiety originated from the attitude toward mathematics teaching from the mathematics teaching anxiety scale and the sub factor of constructivist belief from the mathematics related beliefs produced the value of $(r=-.453 ; p<0.01)$. Accordingly, a negative moderate significant relationship was found between the anxiety levels originated from the attitudes toward mathematics teaching and constructivist beliefs. Therefore, it can be said that the constructivist belief levels increase as the anxiety levels originated from the attitudes toward mathematics teaching decrease. Similarly, it can also be said that the constructivist belief levels decrease as the anxiety levels originated from the attitudes toward mathematics teaching increase. Considering the determination coefficient $\left(r^{2}=0.21\right), 21 \%$ of the total variation of the items regarding the anxiety originated from the attitudes toward mathematics can be interpreted to be related to the constructivist belief levels.

The Pearson's product-moment correlation coefficient analysis which was carried out to examine the relationship between the sub factor of the anxiety originated from the attitude toward mathematics teaching from the mathematics teaching anxiety scale and the sub factor of traditional belief from the mathematics related beliefs 
produced the value of ( $r=-.067 ; \mathrm{p}>0.05)$. Accordingly, a significant relationship could not be found between the anxiety levels originated from the attitude toward mathematics teaching and traditional beliefs.

The Pearson's product-moment correlation coefficient analysis which was carried out to examine the relationship between the sub factor of the anxiety originated from the pedagogical content knowledge from the mathematics teaching anxiety scale and the sub factor of constructivist belief from the mathematics related beliefs produced the value of $(\mathrm{r}=-.476 ; \mathrm{p}<0.01)$. Accordingly, a negative moderate significant relationship was found between the anxiety levels originated from the pedagogical content knowledge and constructivist beliefs. Therefore, it can be said that the constructivist belief levels increase as the anxiety levels originated from the pedagogical content knowledge decrease. Similarly, it can also be said that the constructivist belief levels decrease as the anxiety levels originated from the pedagogical content knowledge increase. Considering the determination coefficient $\left(r^{2}=0.23\right), 23 \%$ of the total variation of the items regarding the anxiety originated from the pedagogical content knowledge can be interpreted to be related to the constructivist belief levels.

The Pearson's product-moment correlation coefficient analysis which was carried out to examine the relationship between the sub factor of the anxiety originated from the pedagogical content knowledge from the mathematics teaching anxiety scale and the sub factor of traditional belief from the mathematics related beliefs produced the value of ( $r=-.110 ; p>0.05)$. Accordingly, a significant relationship could not be found between the anxiety levels originated from the pedagogical content knowledge and traditional beliefs.

\section{Discussions and Conclusion}

The current study examined the relationship between the mathematics anxiety of primary school teachers toward mathematics teaching and their beliefs on mathematics learning and teaching. As aforementioned, there is not any study which examines the relationship between the mathematics anxiety of primary school teachers toward mathematics teaching and their beliefs on mathematics learning and teaching. However, it is also possible to a range of studies which examine the relationship between mathematics teaching and the beliefs on mathematics. For instance, found that there is not a statistically significant difference between mathematics anxiety and the beliefs on mathematics in his study on nursing students. Uusimaki and Nason (2004) concluded that the negative beliefs and mathematics anxieties of classroom primary school teachers toward mathematics have its sources from the instruction in primary schools. Haciömeroğlu (2013) found a low negative relationship between the mathematics anxiety of primary school teachers and their mathematical beliefs. In the current study, a negative moderate significant relationship was found between the mathematics anxiety of primary school teachers toward mathematics teaching and their beliefs on mathematics learning and teaching. Furthermore, a negative moderate significant relationship was found between the anxiety levels originated from content knowledge, the anxiety levels originated from the attitudes toward mathematics teaching, the 
anxiety originated from the pedagogical content knowledge and the sub factor of constructivist beliefs. Also, a negative low significant relationship was found between the anxiety levels originated from self-confidence and the sub factor of constructivist beliefs. However, a significant relationship could not be found between the sub factors of the anxiety scale toward mathematics teaching and the sub factor of traditional belief from the scale of beliefs on mathematics. As there could not be found any study regarding the results of this study, these results were expected to contribute to the literature in the mathematics field.

\section{Suggestions}

- A range of activities can be applied in the classroom to decrease the anxiety levels of pre-service primary school teachers toward mathematics teaching.

- Some applications which improve the constructivist beliefs regarding the mathematics teaching and learning can be encouraged more in the education process of pre-service primary school teachers.

- The anxiety levels toward mathematics teaching and the beliefs on mathematics teaching and learning can be analyzed every year after they start the primary school teaching program, and the changes between years can be scrutinized longitudinally.

- Similar studies can be conducted with the pre-service middle school and high school mathematics teachers.

- The quantitative data collection instruments were used in the current study. The future studies can triangulate with the qualitative data collection instruments. 


\title{
Sınıf Öğretmeni Adaylarının Matematik Öğretimine Yönelik Kaygıları ile Matematik Öğretimi ve Öğrenimine İlişkin İnanışları Arasındaki İlişki ${ }^{*}$
}

\author{
Kübra BAŞPINAR ${ }^{* *}$
}

\author{
Murat PEKER ${ }^{* * *}$
}

Makale Gönderme Tarihi: 09 Kasım 2015

Makale Kabul Tarihi: 08 Aralık 2015

\begin{abstract}
ÖZ: Bu araştırmanın amacı sınıf öğretmeni adaylarının matematik öğretimine ilişkin kaygıları ile matematik öğretimi ve öğrenimine ilişkin inanışları arasındaki ilişkiyi incelemektir. Araştırmanın örneklemini 202'si kız, 48'i erkek olmak üzere toplam 250 sınıf öğretmeni adayı oluşturmaktadır. Veri toplama aracı olarak iki ölçek kullanılmıştır: Bunlardan birincisi; sınıf öğretmeni adaylarının matematik öğretimine ilişkin kaygı düzeylerini belirlemek amacıyla Peker (2006) tarafından geliştirilen, 23 maddeden oluşan, 5’li likert türü Matematik Öğretmeye Yönelik Kayg1 Ölçeğidir. İkincisi; sınıf öğretmeni adaylarının matematiğin öğretimi ve öğrenimine ilişkin inanışlarını belirlemek amacıyla Kayan, Haser ve Işıksal Bostan (2013) tarafından geliştirilen, 26 maddeden oluşan, 5'li likert türü Matematik Hakkındaki İnanışlar Ölçeğidir. Verilerin analizinde Pearson Momentler Çarpımı Korelasyon Katsayısı analizi kullanılmıştır. Araştırma sonucunda; sınıf öğretmeni adaylarının matematik öğretimine ilişkin kaygı puanları ile matematik öğretimine ve öğrenimine ilişkin inanış puanları arasındaki ilişkiyi belirlemek için hesaplanan Pearson Momentler Çarpımı Korelasyon Katsayı değeri ( $\mathrm{r}=-.428$; $\mathrm{p}<0.01)$ bulunmuştur. Yani, sınıf öğretmeni adaylarının matematik öğretimine ilişkin kaygı düzeyleri ile matematik öğretimine ve öğrenimine ilişkin inanışları arasında negatif yönde, orta düzeyde ve anlamlı bir ilişki olduğu tespit edilmiştir.
\end{abstract}

Anahtar kelimeler: matematik; öğretme kaygısı; inanç; öğretmen adayı

\section{Geniş Özet}

Amaç ve Önem: $\mathrm{Bu}$ araştırmanın amacı sınıf öğretmeni adaylarının matematik öğretimine ilişkin kaygıları ile matematik öğretimi ve öğrenimine ilişkin inanışları arasındaki ilişkiyi incelemektir Öğretme ve öğrenme üzerinde etkisi olan iki faktör kaygı ve inançlardır. Öğrencilerin öğrenme kaygıları öğrenme üzerinde pozitif veya negatif etkiye sahiptir. Aynı şekilde öğretmenlerin ya da öğretmen adaylarının öğretme kaygısı öğretmenlerin ya da öğretmen adaylarının öğretmesinde ya da öğrencilerin öğrenmesinde etkiye sahiptir. Literatür incelendiğinde öğretmen adaylarının matematik öğretim kaygıları ile ilgili pek çok araştırmaya rastlanmaktadır (Ertekin, 2010; Ertekin, Dilmaç, Yazıc1, \& Peker, 2010; Peker, 2008; 2009a; 2009b; 2009c; 2015; Peker \& Ertekin, 2011; Ural, 2015; Yazıcı, Peker, Ertekin, \& Dilmaç, 2011). Ancak ulusal ve uluslararası literatür incelendiğinde sınıf öğretmeni adaylarının matematik öğretimine yönelik kaygıları ile matematiğin öğretimi ve öğrenimine ilişkin inanışlarının birlikte incelendiği bir araştırmaya rastlanamamıştır. Bu bağlamda bu araştırmanın sonuçlarının literatürdeki eksikliği giderme anlamında öğretmen yetiştirme programlarında katkısının olacağı düşünülmektedir.

\footnotetext{
* Bu çalışma birinci yazarın yüksek lisans tezinin bir parçasıdır. Ayrıca bu çalışmanın bir kısmı 29-31 Ekim 2015 tarihinde Antalya'da yapılan International Conference on Social Sciences and Education Research konferansinda sunulmuştur.

** Sorumlu Yazar: Öğretmen, Akören Ortaokulu, Afyonkarahisar, Türkiye, kubra_yavasca@hotmail.com

*** Doç. Dr., Afyon Kocatepe Üniversitesi, Afyonkarahisar, Türkiye, peker@aku.edu.tr
} 
Yöntem: Bu çalışma bir betimsel araştırma türü olan ve değişkenler arasındaki ilişkileri olduğu gibi tanımlamaya çalışan ilişkisel tarama türündedir. Araştırma için örneklem seçiminde seçkisiz olmayan örnekleme türlerinden amaçlı örnekleme yöntemi (Büyüköztürk, Kılıç Çakmak, Akgün, Karadeniz, \& Demirel, 2012) kullanılmıştır. Araştırmaya 2014-2015 eğitim öğretim yılında Ege Bölgesi'ndeki bir üniversitede 3. ve 4. sınıfta öğrenimine devam eden 250 sınıf öğretmeni adayı katılmıştır. Örnekleme alınan öğretmen adaylarının 48 tanesi erkek, 202 tanesi ise kızdır. Araştırmada veri toplama aracı olarak iki ölçek kullanılmıştır. Ölçeklerden ilki Peker (2006) tarafından geliştirilen Matematik Öğretimine Yönelik Kaygı Ölçeğidir. Kaygı ölçeği 23 maddeden oluşan, beşli likert tipi, dört faktörlü bir ölçektir. Ölçeklerden ikincisi Kayan, Haser ve Işıksal Bostan (2013) tarafından geliştirilen Matematik Hakkındaki İnanışlar Ölçeğidir. İnanışlar ölçeği 26 maddeden oluşan, beşli likert tipi, iki faktörlü bir ölçektir. Sınıf öğretmeni adaylarının matematik öğretimine yönelik kaygıları ile matematik öğretimi ve öğrenimine ilişkin inanışları arasındaki ilişkiyi belirlemek için Pearson Momentler Çarpımı Korelasyon Katsayısı analizi yapılmıştır.

Bulgular: Sınıf öğretmeni adaylarının matematik öğretimine yönelik kaygıları ile matematik öğretimine ve öğrenimine ilişkin inanışları arasında negatif yönde, orta düzeyde ve anlamlı bir ilişki olduğu görülmektedir. Ayrıca matematik öğretmeye yönelik kaygı ölçeğinin alt faktörleri ile matematik hakkındaki inanışlar ölçeğinin yapılandırmacı inanışlar alt faktörü arasında da negatif yönde anlamlı bir ilişki olduğu sonucuna ulaşılmıştır.

Tartışma ve Sonuçlar: Matematik kaygısı ve matematiksel inançlar arasındaki ilişkinin incelendiği araştırmaların olduğu, bunlardan Walsh (2008) tarafından hemşirelik öğrencileri üzerinde yapılan araştırmada matematik kaygısı ile matematik hakkındaki inançlar arasında anlamlı bir farklılık olmadığı, Uusimaki ve Nason (2004) tarafından sınıf öğretmeni adayları üzerinde yapılan araştırmada matematik hakkındaki negatif inançların ve matematik kaygısının ilkokul eğitimine dayandığı, Hacıömeroğlu (2013) tarafından sınıf öğretmeni adayları üzerinde yapılan araştırmada matematik kaygısı ile matematiksel inançlar arasında negatif yönde düşük düzeyde bir ilişki olduğu belirlenmiştir. $\mathrm{Bu}$ araştırmada ise sınıf öğretmeni adaylarının matematik öğretimine yönelik kaygı düzeyleri ile matematik öğretimine ve öğrenimine ilişkin inanışları arasında negatif yönde, orta düzeyde ve anlamlı bir ilişki olduğu sonucuna ulaşılmıştır. Elde ettiğimiz bu sonuçlar ile ilgili literatürde herhangi bir araştırmaya ulaşılamadığından, bu sonuçların literatüre katkı sağlayacağı düşünülmektedir.

\section{Kaynakça}

Baydar, S. C. \& Bulut, S. (2002). Öğretmenlerin matematiğin doğası ve öğretimi ile ilgili inançların matematik eğitimindeki önemi. Hacettepe Üniversitesi Eğitim Fakültesi Dergisi, 23, 62- 66. 
Büyüköztürk, Ş. (2012). Sosyal bilimler için veri analizi el kitabı. Ankara: PegemA Yayıncilik.

Büyüköztürk, Ş., Kılıç Çakmak, E., Akgün, Ö., Karadeniz, Ş. \& Demirel, F. (2012). Bilimsel Araştırma Yöntemleri. Ankara: PegemA Yayıncılık.

Delice, A., Ertekin, E., Aydın, E., \& Dilmaç, B. (2009). Öğretmen adaylarının matematik kaygısı ile bilgibilimsel inançları arasındaki ilişkinin incelenmesi. Uluslararası İnsan Bilimleri Dergisi, 6(1), 361-375.

Duatepe Paksu, A. (2008). Öğretmenlerin matematik hakkındaki inançlarının branş ve cinsiyet bakımından karşılaştırılması. Hacettepe Üniversitesi Eğitim Fakültesi Dergisi, 35, 87-97.

Ertekin, E. (2010). Correlations between the mathematics teaching anxieties of preservice primary education mathematics teachers and their beliefs about mathematics. Educational Research and Reviews, 5(8), 446-454.

Ertekin, E., Dilmaç, B., Yazıcı, E., \& Peker, M. (2010). The relationship between epistemological beliefs and teaching anxiety in mathematics. Educational Research and Reviews, 5(10), 631-636.

Gardner L., \& Leak G. (1994). Characteristics and correlates of teaching anxiety among college psychology teachers. Teaching of Psychology, 21(1), 28-32.

Hacıömeroğlu, G. (2011). Sınıf öğretmeni adaylarının matematiksel problem çözmeye ilişkin inançlarını yordamada epistemolojik inançlarının incelenmesi. Buca Eğitim Fakültesi Dergisi, 30, 206-220.

Hacıömeroğlu, G. (2013). Mathematics anxiety and mathematics beliefs: What is the relationship in elementary pre-service teachers? IUMPST, 5, 1-9. Retrieved from http://www.k-12prep. math.ttu.edu/journal/attributes/ haciomeroglu02/article.pdf

Haser, Ç. \& Doğan, O. (2012). Preservice mathematics teachers' belief systems. Journal of Education for Teaching, 38(3), 261-274.

Howard, P., Perry, B., \& Lindsay, M. (1997). Secondary mathematics teachers' beliefs about the learning and teaching of mathematics. In People in mathematics education. Proceedings of the 20th Annual Conference of the Mathematics Education Research Group of Australasia (pp. 231-238).

Karakurumer, G. (2003). Matematik ve toplum. 7 Kasım 2015 tarihinde "http://www.matder.org.tr/index.php?option=com_content\&view=article\&id=37:m atematik-ve-toplum-\&catid=8:matematik-kosesi-makaleleri\&Itemid=172" adresinden alınmıştır.

Kayan, F. \& Çakıroğlu, E. (2008). İlköğretim matematik öğretmen adaylarının matematiksel problem çözmeye yönelik inançları. Hacettepe Üniversitesi Ĕgitim Fakültesi Dergisi, 35, 218-226.

Kayan, R., Haser, Ç., \& Bostan Işıksal, M. (2013). Matematik öğretmen adaylarının matematiğin doğası, öğretimi ve öğrenimi hakkındaki inanışları. Eğitim ve Bilim, 38(167), 179-195. 
Köroğlu, H. \& Yeşildere, S.(2004). İlköğretim yedinci sınıf matematik dersi tamsayılar ünitesinde çoklu zeka teorisi tabanlı öğretimin öğrenci başarısına etkisi. GÜ Gazi Eğitim Fakültesi Dergisi, 24(2), 25-41.

Peker, M. (2006). Matematik öğretmeye yönelik kaygı ölçeğinin geliştirilmesi. Eğitim Bilimleri ve Uygulama Dergisi, 9, 73-92.

Peker, M. (2008). Eğitim programları ve öğretmen adaylarının matematik öğretme kaygısı. VIII. Ulusal Fen Bilimleri ve Matematik Eğitimi Kongresi, 27-29 Ağustos 2008, Abant İzzet Baysal Üniversitesi, Bolu.

Peker, M. (2009a). Pre-service teachers' teaching anxiety about mathematics and their learning styles. Eurasia Journal of Mathematics, Science \& Technology Education, 5(4), 335-345.

Peker, M. (2009b). The effects of an instruction using problem solving strategies in Mathematics on the teaching anxiety level of the pre-service primary school teachers. The New Educational Review, 19(3-4), 95-114.

Peker, M. (2009c). The use of expanded microteaching for reducing pre-service teachers' teaching anxiety about mathematics. Scientific Research and Essays, 4(9), 872-880.

Peker, M. (2015). The relationship between mathematics teaching anxiety and selfefficacy beliefs toward mathematics teaching. International Conference on Social Sciences and Education Research 29-31 October, Antalya-Turkey.

Peker, M. \& Ertekin, E. (2011). The relationship between mathematics teaching anxiety and mathematics anxiety. The New Educational Review, 23(1), 213-226.

Raymond, A. M. \& College, K. S. (1997). Inconsistency between a beginning elementary school teacher's mathematics beliefs and teaching practice. Journal for Research in Mathematics Education, 28(5), 550-576.

Sezgin Memnun, D. (2015). Ortaokul beşinci ve altıncı sınıf öğrencilerinin matematik hakkındaki inanç ve tutumlarının nitel ve nicel analizi. Ahi Evran Üniversitesi Kırşehir Eğitim Fakültesi Dergisi, 16(2), 23-42.

Toluk-Uçar, Z. \& Demirsoy, N. H. (2010). Eski-yeni ikilemi: Matematik öğretmenlerinin matematiksel inançları ve uygulamaları. Hacettepe Üniversitesi Ĕ̈itim Fakültesi Dergisi, 39, 321-332.

Turanlı, N., Karakaş Türker, N., \& Keçeli, V. (2008). Matematik alan derslerine yönelik tutum ölçeği geliştirilmesi. Hacettepe Üniversitesi Ĕ̆itim Fakültesi Dergisi, 34, 254-262.

Umay, A. (2003). Matematiksel muhakeme yeteneği. Hacettepe Üniversitesi Ĕ̆itim Fakültesi Dergisi, 24, 234-243.

Ural, A. (2015). Matematik öz-yeterlik algısının matematik öğretmeye yönelik kaygıya etkisi. Kuramsal Eğitimbilim Dergisi, 8(2), 173-184.

Uusimaki, L. \& Nason, R. (2004, July). Causes underlying pre-service teachers' negative beliefs and anxieties about mathematics. In Proceedings of the 28th 
Conference of the International Group for the Psychology of Mathematics Education (Vol. 4, pp. 369-376).

Walsh, K. A. (2008). The Relationship among mathematics anxiety, beliefs about mathematics, mathematics self-efficacy, and mathematics performance in associate degree nursing students. Nursing Education Perspectives, 29(4), 226-229.

Yazıcı, E., Peker, M., Ertekin, E., \& Dilmaç, B. (2011). Is there a relationship between pre-service teachers' mathematical values and their teaching anxieties in mathematics? Electronic Journal of Research in Educational Psychology, 9(1), 263-282.

Yenilmez, K. \& Can, S. (2006). Matematik öğretimi dersine yönelik görüşler. Ondokuz Mayıs Üniversitesi Ĕ̈itim Fakültesi Dergisi, 22, 47-59.

Yenilmez, K. \& Özbey, N. (2006). Özel okul ve devlet okulu öğrencilerinin matematik kaygı düzeyleri üzerine bir araştırma. Uludağ Üniversitesi Ĕgitim Fakültesi Dergisi, 19(2), 431-448.

Yüksel-Şahin, F. (2004). Ortaöğretim öğrencilerinin ve üniversite öğrencilerinin matematik korku düzeyleri. Ĕ̆itim Bilimleri ve Uygulama, 3(5), 57-74. 